\title{
Photochemistry of Compounds of the Main Group Elements
}

BY J. M. KELLY

\section{Introduction}

Reports on the photochemistry of inorganic anions are discussed in the next section; those dealing with other compounds are considered under the particular element.

\section{Anions}

Irradiation $(\lambda>340 \mathrm{~nm})$ has no effect on solutions of aqueous nitrite ion in the presence of thallous or sodium ions. However, $\mathrm{TINO}_{2}$ in DMF or DMSO solutions undergoes decomposition, presumably due to charge transfer in the ion pair. ${ }^{1}$ The production of ammonia following u.v. irradiation of nitrite ion in the presence of hydrocarbons has been discussed. ${ }^{2}$

Phosphate radicals formed upon photolysis of peroxodiphosphate ions in aqueous solution [equation (1)] have been characterized by the e.s.r. spectra of their fumaric and maleic acid adducts. ${ }^{3}$

$$
\mathrm{P}_{2} \mathrm{O}_{8}{ }^{2-} \longrightarrow 2 \mathrm{PO}_{4}{ }^{--}
$$

The quenching of the fluorescence of anionic pyrene derivatives by halide ions has been studied both in inverse micelles ${ }^{4}$ and in sodium dodecyl sulphate micelles. ${ }^{5}$

\section{Alkali and Alkaline Earth Metals}

The quantum yield for the photoelimination of propene from the valerophenone derivative (1) of dibenzo-18-crown- 6 is increased by five-fold and ten-fold, respectively, upon co-ordination with sodium or potassium ions. ${ }^{6}$ It is not yet clear whether this effect is caused by an increase in the hydrogen abstraction rate or by a decrease in the rate of radiationless decay of the reactive excited state.

The non-exponential decay of the phosphorescence observed from ethanolic glasses of acetylacetonate complexes of alkali metals and of alkaline earth metals

1 J. Cunningham, J. O'Shea, P. Reddan, and A. Walker, J. Photochem., 1977, 7, 185.

2 G. L. Petriconi and H. M. Papee, Water Air Soil Pollution, 1977, 8, 217, 225.

3 P. Maruthamuthu and H. Taniguchi, J. Phys. Chem., 1977, 81, 1944.

4 D. J. Miller, U. K. A. Klein, and M. Hauser, J.C.S. Faraday I, 1977, 73, 1654.

5 F. H. Quina and V. G. Toscano, J. Phys. Chem., 1977, 81, 1750.

6 R. R. Hautala and R. H. Hastings, J. Amer. Chem. Soc., 1978, 100, 648. 
<smiles>CC(C)Cc1ccc2c(c1)OCCOCCOc1ccccc1OCCOCCO2</smiles>

(1)

at $77 \mathrm{~K}$ appears to be due to emission originating from both metal complexes and the free ion. ${ }^{7}$ The observation of singlet-to-triplet absorption in naphthalene and quinoline in the presence of barium ions and the efficient quenching of naphthalene fluorescence by the same ion have been attributed to the heavy ion effect. $^{8}$

Flash photolysis of the sodium salt of 1,1,4,4-tetraphenylbutane dianion leads to photoejection of an electron [equation (2)], but not to dissociation [equation (3)].9,10 The product formed decomposes within $100 \mu$ s as shown in equation (4). Photolysis of dilithioacetylene in liquid ammonia produces a compound which is believed to be tetralithiotetrahedrane. ${ }^{11}$

$$
\begin{aligned}
& \mathrm{Na}^{+} \mathrm{Ph}_{2} \overline{\mathrm{C}} \mathrm{CH}_{2} \mathrm{CH}_{2} \overline{\mathrm{C}} \mathrm{Ph}_{2} \mathrm{Na}^{+} \stackrel{h v}{\longrightarrow} \mathrm{Na}^{+} \mathrm{Ph}_{2} \overline{\mathrm{C}} \mathrm{CH}_{2} \mathrm{CH}_{2} \dot{\mathrm{C}} \mathrm{Ph}_{2}+\mathrm{Na}^{+}, \mathrm{e}^{-} \\
& \mathrm{Na}+\mathrm{Ph}_{2} \overline{\mathrm{C} C H}{ }_{2} \mathrm{CH}_{2} \overline{\mathrm{C}} \mathrm{Ph}_{2} \mathrm{Na}^{+} \stackrel{h_{\nu}}{\longrightarrow} 2 \mathrm{Na}+\left[\mathrm{CPh}_{2}=\mathrm{CH}_{2}\right]^{\circ-} \\
& \mathrm{Na}^{+} \mathrm{Ph}_{2} \overline{\mathrm{C}} \mathrm{CH}_{2} \mathrm{CH}_{2} \dot{\mathrm{C}} \mathrm{Ph}_{2} \longrightarrow \mathrm{Na}^{+}\left[\mathrm{CPh}_{2}=\mathrm{CH}_{2}\right]^{--}+\mathrm{CPh}_{2}=\mathrm{CH}_{2}
\end{aligned}
$$

\section{Boron}

The conversion of alkyl- and cycloalkyl-substituted dienylboranes (2) into boracyclopentenes (3) proceeds by initial trans-to-cis isomerization and rapid thermal cyclization of the cis-dienylborane (4). ${ }^{12}$ Isomerization trans-to-cis has also been observed for boronic esters (5). ${ }^{13}$ Surprisingly the phenanthrene derivative

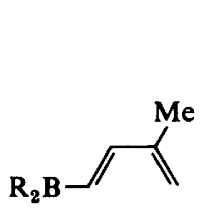

(2)<smiles>[R]B1CC([R])=CC1[R]</smiles>

(3)<smiles>[R]B([R])/C=C\C(=C)C</smiles>

(4)<smiles>COC(=Cc1ccccc1)C(C)(C)C</smiles>

(5)

7 J. A. Kemlo, J. D. Neilson, and T. M. Shepherd, J. Inorg. Nuclear Chem., 1977, 39, 1945.

8 A. M. P. C. De Amorim, H. D. Burrows, S. J. Formosinho, and A. M. Da Silva, Spectrochim. Acta, 1977, 33A, 245.

- H. C. Wang, E. D. Lillie, S. Slomkowski, G. Levin, and M. Szwarc, J. Amer. Chem. Soc., $1977,99,4612$.

10 M. Szwarc, H. C. Wang, and G. Levin, Chem. Phys. Letters, 1977, 51, 296.

11 G. Rauscher, T. Clark, D. Poppinger, and P. V. R. Scheyer, Angew. Chem., 1978, 90, 306; Angew. Chem. Internat. Edn., 1978, 17, 276.

12 G. Zweifel, S. J. Backlund, and T. Leung, J. Amer. Chem. Soc., 1977, 99, 5192.

13 A. Hassner and J. A. Soderquist, J. Organometallic Chem., 1977, 131, C1. 


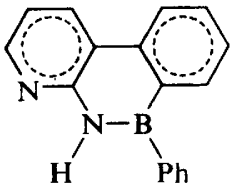

(6)<smiles>[R]B1OC([R])([R])C([R])([R])O1</smiles>

(7) $\mathbf{R}^{\mathbf{1}}$ = cyclopentyl, cyclohexyl, $\mathrm{Bu}^{8}, \mathrm{Pr}^{\mathrm{n}}$, or $\mathrm{n}-\mathrm{C}_{8} \mathrm{H}_{17}$

$\mathbf{R}^{2}=\mathrm{H}$ or $\mathrm{Me}$ $\mathbf{R}^{3}=\mathbf{H}$ or $\mathbf{M e}$

(6) is not formed upon photolysis of (2-pyridylamino)diphenylborane, although irradiation of mixtures of 2-aminopyridine and chlorodiphenylborane does indeed yield (6). ${ }^{14}$

Photolysis of trialkylboranes $\mathrm{BR}_{3}$ in solutions of alcohols gives substituted dioxaboralanes (7), both in the presence and absence of air. ${ }^{15}$

The emission of the triplet state of benzophenone at $77 \mathrm{~K}$ is quenched by boron trichloride and replaced by an unstructured emission attributed to the phosphorescence of $\mathrm{Ph}_{2} \mathrm{C}=\mathrm{O}^{+} \cdots \mathrm{BCl}_{3} .^{16}$ Similarly the photochemical properties of eucarvone are altered in the presence of $\mathrm{BX}_{3}(\mathrm{X}=\mathrm{F}, \mathrm{Cl}$, or $\mathrm{Br})$ due to formation of donor-acceptor complexes. ${ }^{17}$

The conversion of diborane into higher boranes using intense i.r. radiation from a $\mathrm{CO}_{2}$ laser has been re-examined. ${ }^{18,19}$ By use of a chopped beam method it has been demonstrated that $\mathrm{B}_{20} \mathrm{H}_{16}$ is produced via thermal reaction rather than by controlled vibration excitation. ${ }^{18}$ Other publications consider mass spectroscopic photo-ionization evidence for the cleavage of a basal $\mathbf{B}-\mathbf{H}$ bond during mercury-sensitized dissociation of $\mathrm{B}_{5} \mathrm{H}_{9},{ }^{20}$ the photo-isomerization of bis[ $\pi$-(3)-1,2-dicarbollyl]nickel(IV), ${ }^{21}$ and the i.r. laser-induced reaction of boron trichloride and silicon tetrafluoride. ${ }^{22}$

\section{Aluminium}

Upon irradiation in the presence of 1-methylimidazole, carbon dioxide inserts into the $\mathrm{Al}-\mathrm{C}$ bond of (TPP)AlEt (TPP = tetraphenylporphin) giving (TPP) $\mathrm{AlO}_{2} \mathrm{CEt}^{23}$

\section{Thallium}

The radical polymerization of methyl methacrylate upon irradiation of thallous ions in sulphuric acid, ${ }^{24}$ and the decomposition of $\mathrm{TINO}_{2}$ in non-aqueous solvents, ${ }^{1}$ have been the subjects of recent publications.

14 K. D. Mueller and K. Niedenzu, Inorg. Chim. Acta, 1977, 25, L53.

15 V. V. Chung, K. Inagaki, and M. Itoh, J.C.S. Chem. Comm., 1977, 690.

16 R. Snyder and A. C. Testa, J. Phys. Chem., 1978, 82, 842.

17 R. F. Childs and Y.-C. Hor, Canad. J. Chem., 1977, 55, 3501.

18 C. Riley, S. Shatas, and V. Arkle, J. Amer. Chem. Soc., 1978, 100, 658.

19 S. Shatas, D. Gregory, R. Shatas, and C. Riley, Inorg. Chem., 1978, $17,163$.

20 J.-S. Wang, A. J. DeStefano, and R. F. Porter, Inorg. Chem., 1978, 17, 1374.

21 V. V. Volkov, S. Y. Dvurechenskaya, and V. A. Ershova, Zhur. neorg. Khim., 1977, 22, 3283.

22 Y. A. Adamova, A. V. Pankratov, V. G. Sagitova, A. N. Skachkov, G. I. Stolyarova, and G. V. Shmerling, Khim. vysok. Energii, 1978, $12,89$.

23 S. Inoue and N. Takeda, Bull. Chem. Soc. Japan, 1977, 50, 984.

24 V. S. Balasubramanian, Q. Anwaruddin, and L. V. Natarajan, J. Polymer Sci., Polymer Letters, 1977, 15, 599. 


\section{Silicon}

Photocleavage of the silicion-to-silicon bond in organopolysilanes has proved a useful process for the preparation of silacyclopropanes, silacyclopropenes, silaethylenes, and silylenes. Ishikawa has recently summarized his group's previous efforts in this field. ${ }^{25}$

Silacyclopropenes of type (8) are produced upon irradiation of $\left(\mathrm{Me}_{3} \mathrm{Si}\right)_{3} \mathrm{SiPh}$ in the presence of acetylenes (RC $\equiv \mathrm{CR}$ ). ${ }^{26}$ Photolysis of $\mathrm{Me}_{3} \mathrm{SiSiMe}_{2} \mathrm{C} \equiv \mathrm{CPh}$ gives (9). ${ }^{27}$ Although (9) is thermally stable, dimethylsilylene is expelled upon photo-excitation. In the presence of ketones (e.g. acetone) silacyclopropenes form addition products [e.g. compound (10)] probably via attack of the $n-\pi^{*}$ triplet of the ketone. ${ }^{27,} 28$ With nitriles silacyclopropenes photoreact to give adducts (11), presumably after initial formation of (12). ${ }^{29}$

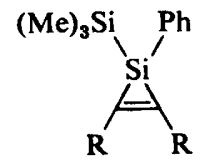

(8)

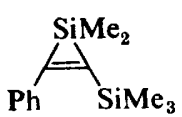

(9)<smiles>C[AsH2]C1=C(c2ccccc2)[Si](C)(C)OC1C</smiles>

(10)<smiles>[R]C1=C([SiH3])N2C1C(c1ccccc1)([Si](C)(C)C)C(c1ccccc1)=C([SiH2]C)[Si]2(C)C</smiles>

(11)<smiles></smiles>

The intermediate species (13) formed upon irradiation of $\mathrm{SiMe}_{3} \mathrm{SiMe}_{2} \mathrm{Ph}$ has been caused to react with arynes ${ }^{30}$ and carbonyl compounds. ${ }^{31}$ A new route to silaethylene derivatives, involving photo-induced 1,3-shifts of a silyl group to the carbon atom of the vinyl group in 1-alkenyldisilanes, has been reported. ${ }^{32}$ Thus species (14) is converted into (15), which has been trapped by methanol. Silaethylenes are also presumed to be formed upon vacuum u.v. excitation $(\lambda=147 \mathrm{~nm})$ of $\mathrm{Me}_{2} \mathrm{SiCH}_{2} \mathrm{CH}_{2} \mathrm{CH}_{2}$ in the gas phase, because in the presence of methanol $\mathrm{Me}_{3} \mathrm{SiOMe}$ is produced. ${ }^{33}$ The reactions of silylenes generated by photolysis of polysilanes with carbonyl compounds, ${ }^{34}$ siloxanes, ${ }^{35}$ and olefins ${ }^{36}$ have been described.

\footnotetext{
M. Ishikawa, Pure Appl. Chem., 1978, 50, 11.
}

M. Ishikawa, K. Nakagawa, and M. Kumada, J. Organometallic Chem., 1977, 131, C15.

H. Sakurai, Y. Kamiyama, and Y. Nakadaira, J. Amer. Chem. Soc., 1977, 99, 3879. D. Seyferth, S. C. Vick, M. L. Shannon, T. F. O. Lim, and D. P. Duncan, J. Organometallic Chem., 1977, 135, C37.

29 H. Sakurai, Y. Kamiyama, and Y. Nakadaira, J.C.S. Chem. Comm., 1978, 80.

so M. Ishikawa, T. Fuchikami, and M. Kumada, J. Organometallic Chem., 1977, $127,261$.

31 M. Ishikawa, T. Fuchikami, and M. Kumada, J. Organometallic Chem., 1977, 133, 19.

32 M. Ishikawa, T. Fuchikami, and M. Kumada, J. Organometallic Chem., 1978, 149, 37.

33 S. Tokach, P. Boudjouk, and R. D. Koob, J. Phys. Chem., 1978, 82, 1203.

34 M. Ishikawa, K. Nakagawa, and M. Kumada, J. Organometallic Chem., 1977, $135, \mathrm{C} 45$.

35 H. Okinoshima and W. P. Weber, J. Organometallic Chem., 1978, 50, C25.

36 M. Ishikawa, K.-I. Nakagawa, M. Ishiguro, F. Ohi, and M. Kumada, J. Organometallic Chem., 1978, 152, 155. 
<smiles>CSC1C=CC=CC1[As](C)(C)C</smiles>

(13)<smiles>C=C([SiH2]C(C)C)c1ccccc1</smiles>

(14)<smiles>C[AsH2]CC(=[AsH2])c1ccccc1</smiles>

(15)

Evidence has been presented for photoreactions of disilanes in DMSO involving the nucleophilic attack of the oxygen atom of the DMSO on the excited state of the disilane. The products formed are substituted silanes, disiloxanes, dimethylsilicone oligomers, and dimethyl sulphide. ${ }^{37}$

Mercury-sensitized cleavage of the $\mathrm{Si}-\mathrm{Si}$ linkage in $\mathrm{Si}_{2} \mathrm{~F}_{6}, \mathrm{Si}_{2} \mathrm{Me}_{6}$, and related compounds provides a useful synthetic route to species of the type $\mathrm{Si}_{2} \mathrm{Me}_{x} \mathrm{~F}_{6-x} \cdot{ }^{38}$ Similarly in the presence of phosphorus trifluoride, mercurysensitized decomposition of $\mathrm{Si}_{2} \mathrm{~F}_{6}$ yields $\mathrm{P}\left(\mathrm{SiF}_{3}\right)_{3} \cdot{ }^{39}$

In the photolysis $(\lambda=185 \mathrm{~nm})$ of hexamethylsiloxane the predominant primary processes are cleavage of the $\mathrm{Si}-\mathrm{C}$ bonds [equations (5) and (6)]; rupture of the $\mathrm{Si}-\mathrm{O}$ linkage is not observed. ${ }^{40}$ This behaviour contrasts with that of dibutyl ether (the carbon analogue), where breaking of the $\mathrm{C}-\mathrm{O}$ bond is the principal primary photoreaction.

$$
\begin{aligned}
& \mathrm{Me}_{3} \mathrm{Si}-\mathrm{O}-\mathrm{SiMe}_{3} \stackrel{h v}{\longrightarrow} \mathrm{Me}_{3} \mathrm{Si}-\mathrm{O}-\mathrm{SiMe}_{2} \cdot+\mathrm{Me} \cdot \\
& \mathrm{Me}_{3} \mathrm{Si}-\mathrm{O}-\mathrm{SiMe}_{3} \stackrel{h v}{\longrightarrow} \mathrm{Me}_{3} \mathrm{Si}-\mathrm{O}-\mathrm{SiMe}=\mathrm{CH}_{2}+\mathrm{CH}_{4}
\end{aligned}
$$

Recent publications on i.r. laser-induced reactions of silicon compounds have described the decomposition of silane, ${ }^{41}$ and the use of silicon tetrafluoride as a sensitizer for reactions such as the isomerization of allene and methylacetylene. ${ }^{42,43}$

\section{Germanium, Tin, and Lead}

Investigations of the formation of persistent tervalent germanium- and tincentred amide radicals by irradiation of the corresponding bivalent amides [equation (7)] has now been extended to compounds having $\mathrm{R}=\mathrm{GeEt}_{3}$ or $\mathrm{GeMe}_{3} .{ }^{44}$ However, with bulkier amide ligands such as those where $\mathrm{R}=\mathrm{SiEt}_{3}$ or $\mathrm{GePh}_{3}$, photolysis of the bivalent amide does not generate the tervalent amide, although the corresponding aminyl radical $\mathrm{NR}_{2}$ could be detected. Related publications have described the photochemical generation of persistent triaryl-

37 H. Okinoshima and W. P. Weber, J. Organometallic Chem., 1978, 149, 179.

38 K. G. Sharp and P. A. Sutor, J. Amer. Chem. Soc., 1977, 99, 8046.

39 K. G. Sharp, J.C.S. Chem. Comm., 1977, 564.

40 H.-P. Schuchmann, A. Ritter, and C. von Sonntag, J. Organometallic Chem., 148, 213.

41 A. N. Oraevskii, A. V. Pankratov, A. N. Skachkov, and V. M. Shabarshin, Khim. vysok. Energii, 1978, 12, 59.

42 C. Cheng and P. Keehn, J. Amer. Chem. Soc., 1977, 99, 5808.

43 K. J. Olszyna, E. Grunwald, P. M. Keehn, and S. P. Anderson, Tetrahedron Letters, 1977, 1609.

44 M. J. S. Gynane, D. H. Harris, M. F. Lappert, P. P. Power, P. Riviere, and M. RiviereBaudet, J.C.S. Dalton, 1977, 2004. 
germanium compounds, ${ }^{45}$ and the spin-trapping of other germyl radicals with nitrones. ${ }^{46}$

$$
2 \mathrm{M}\left(\mathrm{NR}_{2}\right)_{2} \stackrel{h_{\nu}}{\longrightarrow} \mathrm{M}\left(\mathrm{NR}_{2}\right)_{3}+{ }^{\prime} \mathrm{M}\left(\mathrm{NR}_{2}\right)^{\prime}
$$

Tin(iil) radicals are conveniently produced by photolysis of $\left(\eta^{1}-\mathrm{C}_{5} \mathrm{H}_{5}\right)$-tin(Iv) complexes [equation (8)], and this procedure has been recommended as an alternative to the photocleavage of distannanes as a method for the generation

$$
\left(\eta^{1}-\mathrm{C}_{5} \mathrm{H}_{5}\right) \mathrm{SnR}_{3} \longrightarrow \mathrm{C}_{5} \mathrm{H}_{5^{*}}+\mathrm{SnR}_{3} \quad(\mathrm{R}=\mathrm{Cp} \text { or } \mathrm{Bu})
$$

of such radicals. ${ }^{47}$ Other reports consider the formation of $S_{n} R_{2}$ species $(\mathrm{R}=\mathrm{Ph}$ or $\mathrm{Me})$ from the corresponding dimethyl- ${ }^{48}$ or diphenyl-tin polymers. ${ }^{49}$

Photolysis of (16) gives perylene in high yield.50 The photocyclization of $\mathrm{Me}_{3} \mathrm{SnCPh}=\mathrm{CPh}_{2}$ in the presence of oxygen yields (17). ${ }^{51}$

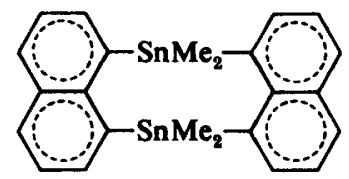

(16)

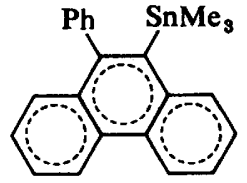

(17)

Irradiation of the CT complexes of $R_{4} S n(R=M e, E t$, or $P h)$ and tetracyanoethylene induces insertion of the olefin into the metal-carbon bond [equation (9)]. ${ }^{52}$ Similarly $\mathrm{Sn}_{2} \mathrm{R}_{6}$ or $\mathrm{Pb}_{2} \mathrm{Ph}_{6}$ form CT complexes with phenanthroquinone $(\mathrm{PQ})$ and photolysis of these yields adducts of the kind $\mathrm{R}_{3} \mathrm{M}, \mathrm{PQ}$, which may be detected by e.s.r.

$$
\mathrm{R}_{4} \mathrm{Sn}+(\mathrm{NC})_{2} \mathrm{C}=\mathrm{C}(\mathrm{CN})_{2} \stackrel{h_{\nu}}{\longrightarrow} \mathrm{R}_{3} \mathrm{Sn}-\mathrm{C}(\mathrm{CN})_{2}=\mathrm{C}(\mathrm{CN})_{2} \mathrm{R}
$$

The quenching of the phosphorescence of $\mathrm{MPh}_{4}(\mathrm{M}=\mathrm{C}, \mathrm{Si}, \mathrm{Ge}, \mathrm{Sn}$, or $\mathrm{Pb})$ and of $\mathrm{SnR}_{4}\left(\mathrm{R}=\mathrm{Me}, \mathrm{Bu}^{\mathrm{n}}\right.$, or $\left.\mathrm{C}_{5} \mathrm{H}_{11^{2}}\right)$ by oxygen in ethanol glasses has been investigated. The quenching process is attributed to complex formation between the organometallic compounds and oxygen. ${ }^{53}$ Other publications deal with the

4 M. J. S. Gynane, M. F. Lappert, P. Riviere, and M. Riviere-Baudet, J. Organometallic Chem., 1977, 142, C9.

46 P. Riviere, S. Richelme, M. Riviere-Baudet, J. Satge, M. J. S. Gynane, and M. F. Lappert, J. Chem. Res. $(S), 1978,218$.

47 A. G. Davies and M.-W. Tse, J.C.S. Chem. Comm., 1978, 353.

48 K. Kuno, K. Kobayashi, M. Kawanisi, S. Kozima, and T. Hitomi, J. Organometalic Chem., 1977, 137, 349.

49 K. Kobayashi, K. Kuno, M. Kawanisi, and S. Kozima, Bull. Chem. Soc. Japan, 1977, 50, 1353.

so J. Meinwald, S. Knapp, T. Tatsuoka, J. Finer, and J. Clardy, Tetrahedron Letters, 1977, 2247.

s1 C. J. Cardin, D. J. Cardin, J. M. Kelly, D. J. H. L. Kirwan, R. J. Norton, and A. Roy, Proc. Roy. Irish Acad., 1978, 77, 365.

52 K. Mochida, J. K. Kochi, K. S. Chen, and J. K. S. Wan, J. Amer. Chem. Soc., 1978, 100, 2927.

53 G. A. Razuvaev, A. N. Egorochkin, V. A. Kuznetsov, V. N. Glushakova, A. V. Shabanov, Y. A. Alexandrov, and Y. Y. Baryshnikov, J. Organometallic Chem., 1978, $148,147$. 
quenching of the fluorescence of 9-cyanoanthracene by $\mathrm{Me}_{2} \mathrm{~N}\left(\mathrm{CH}_{2}\right)_{3} \mathrm{SnMe}_{3},{ }^{54}$ the photoreduction of bridgehead halides with organotin hydrides, ${ }^{55}$ the photodecomposition of dialkylgermyl- and dialkylstannyl-tetraphenylporphyrin complexes, ${ }^{56}$ and the catalysed photoreduction of nitrobenzene using tin tetraphenylporphyrin complexes. ${ }^{57}$

\section{Nitrogen, Phosphorus, Arsenic, and Antimony}

The bis(trimethylsilyl)aminyl radical may be conveniently prepared by reaction (10), and its adducts with ethylene, triethylphosphite, and t-butylisocyanide have been characterized by e.s.r. ${ }^{58}$

$$
\left(\mathrm{Me}_{3} \mathrm{Si}\right)_{2} \mathrm{NN}\left(\mathrm{SiMe}_{3}\right)_{2} \stackrel{h \nu}{\longrightarrow} 2 \dot{\mathrm{N}}\left(\mathrm{SiMe}_{3}\right)_{2}
$$

Other authors have reported the low-temperature synthesis of $\left[\mathrm{NF}_{4}\right]^{+}$by u.v. photolysis of $\mathrm{NF}_{3}-\mathrm{F}_{2}-\mathrm{AsF}_{5}$ or $\mathrm{NF}_{3}-\mathrm{F}_{2}-\mathrm{BF}_{3}$ mixtures, ${ }^{59}$ the conversion of nitrosyl chloride to chlorine nitrate upon photoexcitation in oxygen matrices at $10 \mathrm{~K},{ }^{60}$ the photoreaction of nitrogen dioxide on sodium chloride at $77 \mathrm{~K},{ }^{61}$ and the photodissociation of dinitrogen tetrafluoride by $\mathrm{CO}_{2}$ laser pulses. ${ }^{62}$

The phosphorescence of $\mathrm{MPh}_{3}(\mathrm{M}=\mathrm{N}, \mathrm{P}, \mathrm{As}$, or $\mathrm{Sb})$ in ethanol glasses is quenched by oxygen, apparently through formation of a CT complex. ${ }^{63}$

E.s.r. studies have shown that photolysis of $\mathrm{Ph}_{3} \mathrm{P}=\mathrm{CHCO}_{2} \mathrm{Et}$ causes production of triphenylphosphine and the carbene. Secondary photoreactions then yield $\cdot \mathrm{PPh}_{2}$ and $\cdot \mathrm{PPh}_{2}=\mathrm{CHCO}_{2} \mathrm{Et}^{64}$ The light-accelerated decomposition of 1,2-diphenyldiphosphine, the reaction of phosphorus pentafluoride and sulphur dioxide induced by intense i.r. radiation, ${ }^{65}$ the photodissociation of arsenic tri-iodide in molecular beams, ${ }^{66}$ the photosynthesis of arsenic pentachloride from its trichloride and chlorine, ${ }^{67}$ the photosensitivity of silver-doped arsenic sulphide systems, ${ }^{68}$ and the initiation of polymerization of methyl methacrylate by photolysis of pentaphenylantimony, ${ }^{69}$ have been the subjects of recent papers.

\section{Oxygen, Sulphur, Selenium, and Tellurium}

Reports on the photo-oxidation of sulphur ${ }^{70}$ and of ascorbic acid ${ }^{71}$ by hydrogen peroxide have been published.

54 D. E. Vander Donckt, M. R. Barthels, N. Antheunis, and M. Swinnen, Mol. Photochem., $1977,8,121$.

ss T.-Y. Luh and L. M. Stock, J. Org. Chem., 1977, 42, 2790.

56 C. Cloutour, D. Lafargue, J. A. Richards, and J. C. Pommier, J. Organometallic Chem., 1977, 137, 157.

57 Y. Harel and J. Manassen, J. Amer. Chem. Soc., 1977, 99, 5817.

58 B. P. Roberts and J. N. Winter, J.C.S. Chem. Comm., 1978, 545.

59 K. O. Christe and I. B. Goldberg, Inorg. Chem., 1978, 17, 759.

60 D. E. Tevault and R. R. Smardewski, J. Phys. Chem., 1978, 82, 375.

61 H. D. Breuer and J. Krueger, Ber. Bunsengesellschaft Phys. Chem., 1978, $82,97$.

62 P. Lavigne, J. L. Lachambre, and G. Otis, Optics Comm., 1977, $22,75$.

63 M. Zanger and R. Poupko, Spectroscopy Letters, 1977, 10, 737.

64 M. Baudler, B. Carlsohn, D. Koch, and P. K. Medda, Chem. Ber., 1978, 111, 1210.

65 V. D. Klimov, V. A. Kuz'menko, and V. A. Legasov, Zhur. fiz. Khim., 1977, $51,949$.

66 M. Kawasaki and R. Bersohn, J. Chem. Phys., 1978, 68, 2105.

67 K. Seppelt, $Z$. anorg. Chem., 1977, 434, 5.

68 M. T. Kostyshin and V. I. Min'ko, Ukrain. fiz. Zhur., 1977, 22, 1560.

69 H. Matsuda, T. Isaka, and N. Iwamoto, Makromol. Chem., 1978, 179, 539.

70 I. N. Barshchevskii, Zhur. fiz. Khim., 1977, 51, 2269.

71 E. V. Shtamm, A. Purmalis, and Y. I. Skurlatov, Zhur. fiz. Khim., 1978, 52, 117. 
E.s.r. evidence has been presented for the cleavage of $\mathbf{S}-\mathbf{S}$ bonds in arene thiosulphonates [e.g. reaction (11)], the radicals so produced reacting further to give arene sulphinyl radicals [equation (12)]. ${ }^{72}$ Presumably rupture of the<smiles>O=S(=O)(Sc1ccccc1)c1ccccc1</smiles>

$\mathrm{PhSO}_{2} \cdot+\mathrm{PhS} \cdot \longrightarrow$ 2PhSO $-\mathrm{O} \cdot$

$\mathbf{S}-\mathbf{S}$ bond is also the primary process upon irradiation of $\mathbf{P h S}-\mathbf{S P h}$, which leads to (18), a versatile chelating ligand. ${ }^{73}$ Dibenzylditelluride is photolysed to dibenzyltelluride, which upon irradiation in the presence of oxygen reacts further to give tellurium-free products. ${ }^{74}$<smiles>c1ccc(Sc2ccccc2SSc2ccccc2Sc2ccccc2)cc1</smiles>

(18)

Photochemical syntheses of arylphenylselenides from arylhalides and phenylselenide anion in liquid ammonia have been described. ${ }^{75}$ The primary process seems to involve an electron transfer step of the type shown in equation (13).

$$
\mathrm{ArX}+\mathrm{PhSe}^{-} \longrightarrow \mathrm{ArX}^{-}+\mathrm{PhSe} \text {. }
$$

Photoaddition of alkynes or alkenes to benzoselenophene, ${ }^{76}$ the photochemical decomposition and isomerization of (19), ${ }^{77}$ a study of the phosphorescence and intersystem crossing in compounds $(20),{ }^{78}$ and the photopolymerization of $\mathrm{S}_{2} \mathrm{~N}_{2}{ }^{79}$ have been discussed recently.

At room temperature, substituted 1,2,4- and 1,2,5-selenadiazoles (21), (22) photodissociate to nitriles and selenium. $.^{\mathbf{8 0}}, 81$ At low temperatures or in nitrogen matrices, spectroscopic data indicated that the nitrile selenide RCNSe is formed

B. C. Gilbert, B. Gill, and M. D. Sexton, J.C.S. Chem. Comm., 1978, 78.

73 S. D. Killops, S. A. R. Knox, G. H. Riding, and A. J. Welch, J.C.S. Chem. Comm., 1978, 486.

74 H. K. Spencer and M. P. Cava, J. Org. Chem., 1977, 42, 2937.

75 A. B. Pierini and R. A. Rossi, J. Organometallic Chem., 1978, 144, C12.

76 Tran Quang Minh, L. Christaens, P. Grandclaudon, and A. Lablache-Combier, Tetrahedron, 1977, 33, 2225.

77 G. Höhne, W. Lohner, K. Praefcke, U. Schulze, and H. Simon, Tetrahedron Letters, 1978,613 .

78 P. Jardon, J. Chim. phys., 1977, 74, 1177.

79 P. Love, H. I. Kao, G. H. Meyer, and M. M. Labes, J.C.S. Chem. Comm., 1978, 301.

80 C. L. Pedersen, N. Harrit, M. Poliakoff, and I. Dunkin, Acta Chem. Scand., 1977, B31, 848.

81 C. L. Pedersen and N. Hacker, Tetrahedron Letters, 1977, 3981. 
<smiles>COc1ccccc1C(=O)[Te]c1ccc(C)cc1</smiles>

(19)<smiles>[X]c1ccccc1[X]c1ccccc1[X]</smiles>

(20) $X=O, S$, or $\mathrm{Se}$

$Y=\mathrm{O}, \mathrm{S}, \mathrm{Se}, \mathrm{Te}$, or $\mathrm{CH}_{\mathbf{2}}$<smiles>[R]c1n[se]c([R])n1</smiles>

(21)<smiles>[R]c1n[se]nc1[R]</smiles>

(22)

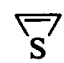

(23)<smiles>c1csnn1</smiles>

(24)

as the initial product. Irradiation of 1,2,3-thiadiazole (23) isolated in argon matrices at $8 \mathrm{~K}$ yields thiirene (24). ${ }^{82}$

The decomposition of $\mathrm{SF}_{6}{ }^{83-88} \mathrm{SF}_{5} \mathrm{Cl}^{89}$ and $\mathrm{SeF}_{6}{ }^{90}$ induced by i.r. laser irradiation continues to attract attention.

\section{Halogens}

Photodecomposition of fluorine in low-temperature matrices containing other halogens gives rise to species of type $\mathrm{XF}_{2}, \mathrm{X}_{2} \mathrm{~F}$, and $\mathrm{X}_{2} \mathrm{~F}_{2} \cdot{ }^{91} \mathrm{~A}$ study has been carried out on the properties of the excited state of xenon monofiuoride formed upon vacuum u.v. photolysis of xenon difluoride. ${ }^{92}$

82 A. Krantz and J. Laureni, Ber. Bunsengesellschaft Phys. Chem., 1978, 82, 13.

83 R. V. Ambartsumyan, Y. A. Gorokhov, G. N. Makarov, A. A. Puretskii, and N. P. Furzikov, Springer Ser. Opt. Sci., 1977, 7, 439.

84 Y. I. Arkhangel'skii, V. D. Klimov, V. A. Kuz'menko, V. A. Legasov, and S. L. Nedoseev, Doklady Akad. Nauk S.S.S.R., 1977, 235, 1075.

85 N. Bloembergen and E. Yablonovitch, Springer Ser. Opt. Sci., 1977, 7, 86.

86 G. J. Diebold, F. Engelke, D. M. Lubman, J. C. Whitehead, and R. N. Zare, J. Chem. Phys., 1977, 67, 5407.

87 E. R. Grant, M. J. Coggiola, Y. T. Lee, P. A. Schulz, A. S. Sudbo, and Y. R. Shen, Chem. Phys. Letters, 1977, 52, 595.

88 M. Rothschild, W.-S. Tsay, and D. O. Ham, Optics Comm., 1978, 24, 327.

89 K. M. Leary, J. L. Lyman, L. B. Asprey, and S. M. Freund, J. Chem. Phys., 1978, 68, 1671.

90 J. J. Tiee and C. Wittig, Appl. Phys. Letters, 1978, 32, 236.

91 E. S. Prochaska, L. Andrews, N. R. Smyrl, and G. Mamantov, Inorg. Chem., 1978, 17, 970.

92 H. C. Brashears, jun., D. W. Setser, and D. Desmarteau, Chem. Phys. Letters, 1977, $48,84$. 